\title{
Initial development of Dipteryx alata Vog consortium with cover plants
}

\author{
Desenvolvimento inicial de Dipteryx alata Vog consorciado com plantas de cobertura \\ Desarrollo inicial del consorcio Dipteryx alata Vog con plantas de cubierta
}

Received: 03/08/2021 | Reviewed: 03/17/2021 | Accept: 03/18/2021 | Published: 03/27/2021

\author{
Kennedy de Araújo Barbosa \\ ORCID: https://orcid.org/0000-0002-1157-6377 \\ Instituto Federal de Educação, Ciência e Tecnologia Goiano, Brasil \\ E-mail: kennedy.barbosa@ifgoiano.edu.br \\ Fabiano Guimarães Silva \\ ORCID: https://orcid.org/0000-0002-2127-8402 \\ Instituto Federal de Educação, Ciência e Tecnologia Goiano, Brasil \\ E-mail: fabiano.silva@ifgoiano.edu.br \\ Adriano Perin \\ ORCID: https://orcid.org/0000-0001-9399-7599 \\ Instituto Federal de Educação, Ciência e Tecnologia Goiano, Brasil \\ E-mail: adriano.perin@ifgoiano.edu.br \\ Paulo Dornelles \\ ORCID: https://orcid.org/0000-0002-6152-1999 \\ Instituto Federal de Educação, Ciência e Tecnologia Goiano, Brasil \\ E-mail: dornellesifgoiano@gmail.com \\ Aniela Pilar Campos de Melo \\ ORCID: https://orcid.org/0000-0002-5687-5928 \\ Instituto Federal de Educação, Ciência e Tecnologia Goiano, Brasil \\ E-mail: aniela.pilar@ifgoiano.edu.br \\ Aurélio Rubio Neto \\ ORCID: https://orcid.org/0000-0003-0517-1223 \\ Instituto Federal de Educação, Ciência e Tecnologia Goiano, Brasil \\ E-mail: aurelio.rubio@ifgoiano.edu.br \\ Diego Pinheiro Dornelles \\ ORCID: https://orcid.org/0000-0003-3714-609X \\ Instituto Federal de Educação, Ciência e Tecnologia Goiano, Brasil \\ E-mail: dornelles-diego@hotmail.com \\ Bruno Matheus Mendes Dário \\ ORCID: https://orcid.org/0000-0002-6746-0752 \\ Instituto Federal de Educação, Ciência e Tecnologia Goiano, Brasil \\ E-mail: bruno.dario@estudante.ifgoiano.edu.br
}

\begin{abstract}
Cover plants, due to their high biomass production capacity, and plants provide the soil with several benefits such as nutrient cycling, greater water retention and storage capacity, reduced temperature, increased aggregation and microbiota, physical protection against compaction. The objective of this work was to verify the growth of the fruit species of the cerrado, Dipteryx alata Vogel, as a consortium strategy with green fertilizers, Arachis pintoi Krapov. \& W.C.Greg./Callopogonium mucunoides Desv., Crotalaria juncea L, Dolichos lablab L., [Urochloa decumbens (Stapf) R.D.Webster] with nitrogen and [Urochloa decumbens (Stapf) R.D.Webster] without nitrogen (control). The experiment covered the period from 2013 to 2017, in Rio Verde, Goiás, installed in a randomized block design, with five treatments (cover plants) and four replications. The evaluations included the macro and micronutrient contents in $D$. alata, biomass production by cover plants, soil moisture and biometric determinations of D. alata. The use of $U$. decumbens with nitrogen, $D$. lablab and $C$. juncea showed better performances in maintaining soil moisture, growth and early fruiting of $D$. alata, making it advantageous to use these types of consortium in its establishment under conditions of the Cerrado.
\end{abstract}

Keywords: Cerrado fruit; Biomass; Sustainability; Consortium; Green adubation.

\section{Resumo}

As plantas de cobertura, pela elevada capacidade de produção de biomassa, e plantas propiciam ao solo diversos benefícios como ciclagem de nutrientes, maior capacidade de retenção e armazenamento de água, redução na temperatura, aumento na agregação e na microbiota, proteção física contra compactação. Objetivou-se com esse trabalho verificar o crescimento da espécie frutífera do cerrado, Dipteryx alata Vogel, como estratégia de consórcio com adubos verdes, Arachis pintoi Krapov. \& W.C.Greg./Callopogonium mucunoides Desv., Crotalaria juncea L, Dolichos lablab L., [Urochloa decumbens (Stapf) R.D.Webster] com nitrogênio e [Urochloa decumbens (Stapf) R.D.Webster] sem nitrogênio (controle). O experimento compreendeu o período de 2013 a 2017, em Rio Verde, 
Goiás, instalado em delineamento em blocos casualizado, com cinco tratamentos (plantas de cobertura) e quatro repetições. As avaliações compreenderam os teores de macro e micronutrientes no $D$. alata, produção de biomassa pelas plantas de cobertura, umidade do solo e determinações biométricas de D. alata. O uso de U. decumbens com nitrogênio, D. lablab e $C$. juncea apresentaram melhores performances na manutenção de umidade do solo, crescimento e precocidade de frutificação de D. alata, tornando vantajoso o emprego dessas modalidades de consórcio no seu estabelecimento em condições do Cerrado.

Palavras-chave: Fruto do Cerrado; Biomassa; Sustentabilidade; Consórcio; Adubação verde.

\section{Resumen}

Las plantas de cobertura, por su alta capacidad de producción de biomasa, y las plantas aportan al suelo varios beneficios como el ciclo de nutrientes, mayor capacidad de retención y almacenamiento de agua, temperatura reducida, mayor agregación y microbiota, protección física contra la compactación. El objetivo de este trabajo fue verificar el crecimiento de la especie frutal del cerrado, Dipteryx alata Vogel, como estrategia de consorcio con fertilizantes verdes, Arachis pintoi Krapov. \& W.C.Greg./Callopogonium mucunoides Desv., Crotalaria juncea L, Dolichos lablab L., [Urochloa decumbens (Stapf) R.D.Webster] con nitrógeno y [Urochloa decumbens (Stapf) R.D.Webster] sin nitrógeno (control). El experimento abarcó el período de 2013 a 2017, en Río Verde, Goiás, instalado en un diseño de bloques al azar, con cinco tratamientos (plantas de cobertura) y cuatro réplicas. Las evaluaciones incluyeron el contenido de macro y micronutrientes en $D$. alata, producción de biomasa por plantas de cobertura, humedad del suelo y determinaciones biométricas de D. alata. El uso de $U$. decumbens con nitrógeno, $D$. lablab y $C$. juncea mostró mejores rendimientos en el mantenimiento de la humedad del suelo, el crecimiento y la fructificación temprana de D. alata, por lo que es ventajoso utilizar este tipo de consorcios en su establecimiento en las condiciones del Cerrado.

Palabras clave: Fruto del Cerrado; Biomasa; Sustentabilidad; Consorcio; Adulación verde.

\section{Introduction}

The Cerrado is a biome with rich biodiversity, accounting for around 11,000 cataloged plant species, many endemic to the region, being recognized as the richest savanna in the world (MMA, 2014). Natural environment for approximately 4,440 plant species and considered one of the 25 global critical points of biodiversity (de Carvalho Mendes et al., 2012). However, the distribution of the remaining natural areas is highly asymmetric in relation to the Cerrado physiognomies.

In the Cerrado the native fruit plants are evident, being a group that adds up to more than 50 species, even in their natural state, they demonstrate adaptability in agricultural system and representative productivity (Andaló et al., 2018; Soares et al., 2018). The most explored potential of the Cerrado is the fruits, in which is consumed naturally or in the form of juices, liqueurs, jellies and savory dishes (de Andrade Silva \& Fonseca, 2016; Donado-Pestana et al., 2018; Franco et al., 2020). The fruits are rich in nutrients, such as minerals, vitamins, amino acids, proteins, carbohydrates and oils. The varied shapes, flavors, aromas and colors represent another important characteristic of the Cerrado fruits (Coradin et al., 2011).

Fruit species found in this Biome are useful for economic use, such as the fruits of Hancornia speciosa Gomes, Bromelia goyazensis Mez, Mauritia flexuosa L.f., Alibertia edulis (Rich.) A.Rich., Byrsonima crassifolia (L.) Kunth, among others (de Andrade Silva \& Fonseca, 2016; Oliveira et al., 2012; Schiassi et al., 2018). Among other species, Dipteryx alata Vog. Stands out, popularly known as "baruzeiro", in addition to other names. It is an imposing tree in the Cerrado due to the large size of the stem and crown, in addition to its environmental importance in biological nitrogen fixation, food for fruit productivity, pharmacological due to its curative and wood properties due to its quality and density, it can be used in various types of construction (Carrazza \& Ávila, 2010).

Integrated cultivation with cover crops in fruit growing is already widely used. Cover crops contribute to sustainable agricultural exploitation with several benefits to the soil and the crop of interest. It is a conservationist practice that aims to improve soil fertility, by maintaining the biomass produced (López-Bellido et al., 2004; Thorup-Kristensen et al., 2003). They assist in soil porosity, water infiltration, nutrient replacement, invasive weed control, with consequent productivity gains in agricultural crops (N. Garcia-Franco et al., 2015; Paulo et al., 2016). The maintenance of cultural remains on the soil surface has been used as an alternative to reduce variations in soil temperature, reduce erosion losses, retain more water and promote higher yields of agricultural crops, in addition to reducing water evaporation, runoff and increased infiltration rate (Gupta et 
al., 2015; Scopel et al., 2013). Cover plants release nutrients, organic acids, amino acids and phytohormones during their decomposition, which can favor intercropped plants (Delarmelinda et al., 2010; Paulo et al., 2016; Schroth et al., 1992). This practice increases the soil's organic matter (Noelia Garcia-Franco et al., 2018) and reduces environmental impacts of the main crop (Nemecek et al., 2015). Provides improvements in various soil attributes and biological nitrogen fixation, nutrient cycling, moisture maintenance, less thermal amplitude of the soil, making the activity of beneficial microorganisms in the soil favorable (Chapin et al., 2011; Corrêa et al., 2014; Júnior de Almeida et al., 2015).

Nevertheless, some specific care is needed regarding the choice of cover plants to be used, as well as species that are of time and growth habit consistent with the management of the fruit tree of economic interest, as well as other effects of coexistence, minimizing the risks of competition (Aguilar-Fenollosa \& Jacas, 2013; Korte \& Porembski, 2010; Norgrove \& Hauser, 2013; Perin et al., 2009). Studies using native fruit trees from the cerrado submitted to the consortium with cover plants are scarce in the literature. Thus, the objective was to evaluate the responses provided by the consortium of $D$. alata with perennial and annual cover plants, in the production of plant biomass, maintenance of soil moisture and effects on the growth and absorption of nutrients from the fruit tree.

\section{Methodology}

The experiment was implemented in the field in December 2013, and the results of this study cover a period of 4 agricultural years (2014 to 2017). Held in an area of Dystroferric Red Latosol, at the Federal Institute of Goiás - Campus Rio

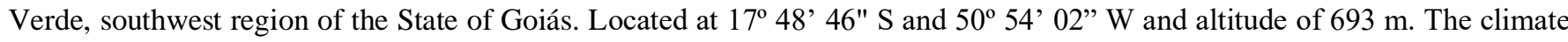
is classified, in the Köppen climatic categories, as Aw, with two defined seasons, with dry winter (from April to September) and hot and humid summer (from October to March), average annual temperature and precipitation of $23.3^{\circ} \mathrm{C}$ and $1,663 \mathrm{~mm}$, respectively.

The experimental design adopted was in randomized blocks (RBD), with five treatments, which represent the five different cover plants Arachis pintoi Krapov. \& W.C.Greg./Callopogonium mucunoides Desv., Crotalaria juncea L, Dolichos lablab L., [Urochloa decumbens (Stapf) R.D.Webster] with nitrogen and [Urochloa decumbens (Stapf) R.D.Webster] (control), with four repetitions. All treatments were combined with $D$. alata. Before the implementation of the experiment, the area was pasture, formed by $U$. decumbens, and then the sowing of this cover plant was dispensed with. The other annual cover plants (C. juncea and D. lablab) were sown annually, in the month of November of each year (rainy season). The treatment formed by the perennial cover plant was initially established by A. pintoi. However, this species showed incompatibility with the dry climate of the region and, after completing 2 years of experiment, it was replaced by $C$. mucunoides.

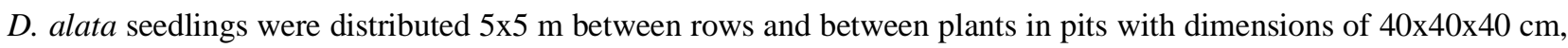
in December 2013. Quantitative measures (biometric) were evalueted in December of each year, with the aid of a ruler, tape measure and topography sight. The height was measured, measuring from the ground to the largest end of the branch. For the stem diameter, a digital caliper $5 \mathrm{~cm}$ from the ground was used. Annually at 150 days after the sowing of the cover plants, for the purpose of assessing biomass production, he used a metal frame of $1 \mathrm{~m}^{2}$, launching randomly in each treatment, being cut the vegetable mass contained inside. These samples were weighed while still green and stored in a forced air circulation oven at $65^{\circ} \mathrm{C}$, for at least 72 hours, to obtain dry matter.

After sampling, the cover plants were mowed with the aid of a tractor and brush cutter, except for A. pintoi and $C$. mucunoides, as they are small cover plants. Covering fertilization was carried out on the $U$. decumbens $+\mathrm{N}$ plot with $220 \mathrm{~g}$ of urea/plant in the crown region, in three stages in the months of November, February and April of each year, equivalent to an annual nitrogen fertilization of $40 \mathrm{~kg}$ ha-1. Annually, after the end of the rainy season (April to September), soil sampling was carried out to determine moisture levels by the gravimetric method, in the $0-5 \mathrm{~cm}$ layer. Then, the samples were taken to the 
laboratory to determine the wet weight, where they were stored in a forced circulation oven at a temperature of $105^{\circ} \mathrm{C}$ for $24 \mathrm{~h}$, weighed to obtain the dry weight according to the methodology described by Apha (2005), with the formula\% Humidity = WW-DW/PUx100, in which: WW = Wet weight of the sample (g); DW = Dry weight of the sample (g). In June, developed leaves of $D$. alata were collected, then washed in distilled water, dried in an oven at $65^{\circ} \mathrm{C}$ until constant mass. They were ground in a Willey mill, to analyze the levels of nutrients present in the plant tissue, according to the methodology described (Malavolta et al., 1997).

To describe the growth curve of height and diameter as a function of days, the Exponential model Yi $=\mathrm{A}$ ekXi+ei, was used, where: $\mathrm{Yi}$ is the height or diameter of the plant on day $\mathrm{Xi}$; represents the estimate of the initial value (height or diameter); $\mathrm{k}$ is the specific growth rate; ei the error associated with each observation which, by presupposition, is NID $\left(\sum 2\right)$. The structure of variance and covariance of errors between the evaluations was verified. To estimate the parameters, the least squares method and the Gauss-Newton algorithm were used. The methodology presented by (Regazzi \& Silva, 2010) was also used to test the identity of nonlinear regression models and the equality of any subset of parameters, using the likelihood ratio test, with the likelihood ratio test, with chi square approximation, at 5\% significance. To perform the likelihood ratio test, an indicator variable (dummy) was created for the representation of the models, which assumes binary values 0 or 1 ; thus, the complete model, with different parameters for the five types of consortia.

The data were submitted to the Shapiro-Wilk normality test, and homogeneity of variances by the Bartlett test, both at $5 \%$ probability. Due to the lack of conformity, non-parametric analysis was performed using the Kruskall-Wallis test, followed by the analysis of main components, and cluster that describes multivariate statistical procedure, serving to identify homogeneous groups in the data, based on variables, allowing the observation of similarities (Landim, 2011). The correlations of the variables were assessed by Pearson's correlation test, studied by (Schuberth et al., 2018) at 5\% probability. For all statistical analyzes performed in this experiment, the statistical program SAS, version 9.2, was used (SAS Institute, Cary, North Carolina, EUA).

\section{Results and Discussion}

The best model to explain growth was that with different initial values between plants, and an equal growth rate (Table 1). When observing the confidence interval of parameter A for height, it was found that the cover plants D. lablab and $U$. decumbens $+\mathrm{N}$, showed higher value than the plant $U$. decumbens (Table 2). As for the diameter of the plants, it was observed that the $U$. decumbens plant had a lower value, where the others differed from each other. A. pintoi /C. mucunoides, also did not differ between themselves and with the other plants (Table 2). Plants grown in consortium with A. pintoi $/ C$. mucunoides, had smaller stem diameter. The other cover crops had no effect on the stem diameter of D. alata. 
Table 1. Likelihood ratio test, using a chi-square $(\chi 2)$, pproximation, to assess the identity of models between cover plants, considering the adjustment of the Exponential model for height.

\begin{tabular}{|c|c|c|c|c|}
\hline Parameters & p & \multicolumn{2}{|c|}{$\chi^{2}$} & Tabulated X \\
\hline \multicolumn{5}{|c|}{ Complete model } \\
\hline \multirow[t]{3}{*}{$\mathrm{Aj} \mathrm{kj}$} & 10 & \multicolumn{2}{|c|}{-} & - \\
\hline & & \multicolumn{2}{|c|}{ Reduced models } & \\
\hline & & Height & Diameter & \\
\hline $\mathrm{Aj} \mathrm{k}$ & 6 & 0.85 & 0.42 & 6.54 \\
\hline $\mathrm{A} \mathrm{k}$ & 2 & 29.6167 & 31.0128 & 15.5 \\
\hline
\end{tabular}

Source: Authors.

Table 2. Estimates and inferior and superior limits, for model parameters considering the adjustment of the Exponential model for height.

\begin{tabular}{|c|c|c|c|c|c|}
\hline Variables & Parameters & Estimate & Standard error & Inferior limit & Superior limit \\
\hline \multirow{6}{*}{ Height } & A1 & 120.8 & 8.72 & 103.70 & 137.90 \\
\hline & $\mathrm{a} 2$ & 122.0 & 8.76 & 104.84 & 139.16 \\
\hline & a3 & 131.1 & 8.25 & 114.92 & 147.28 \\
\hline & $\mathrm{a} 4$ & 142.1 & 9.32 & 123.84 & 160.36 \\
\hline & a5 & 89.51 & 8.61 & 72.64 & 106.38 \\
\hline & $\mathrm{c}$ & 0.00105 & 0.000078 & 0.00089712 & 0.00120288 \\
\hline \multirow{6}{*}{ Diameter } & a1 & 25.8746 & 1.57 & 22.79 & 28.96 \\
\hline & $\mathrm{a} 2$ & 26.5921 & 1.62 & 23.42 & 29.76 \\
\hline & a3 & 28.7861 & 1.75 & 25.35 & 32.22 \\
\hline & $\mathrm{a} 4$ & 26.6815 & 1.62 & 23.50 & 29.86 \\
\hline & a5 & 16.453 & 1.06 & 14.38 & 18.53 \\
\hline & $\mathrm{c}$ & 0.00111 & 0.00009 & 0.0009336 & 0.0012864 \\
\hline
\end{tabular}

Source: Authors.

The largest contribution of the height of the plants during the consortium of D. alata with A. pintoi /C. mucunoides, C. juncea, D. lablab, U. decumbens $+\mathrm{N}$ and $U$. decumbens, can be attributed to the help of vegetation cover (Figure 1), in which, it may have provided lower temperature, easier maintenance of soil microbiota and better water absorption (Van Deynze et al., 2018). Similar results regarding the N values were observed by (Coelho et al., 2012; Gitti et al., 2012). 
Figure 1. Initial growth of Dipteryx alata plants grown for 4 years in consortium with different cover plants.

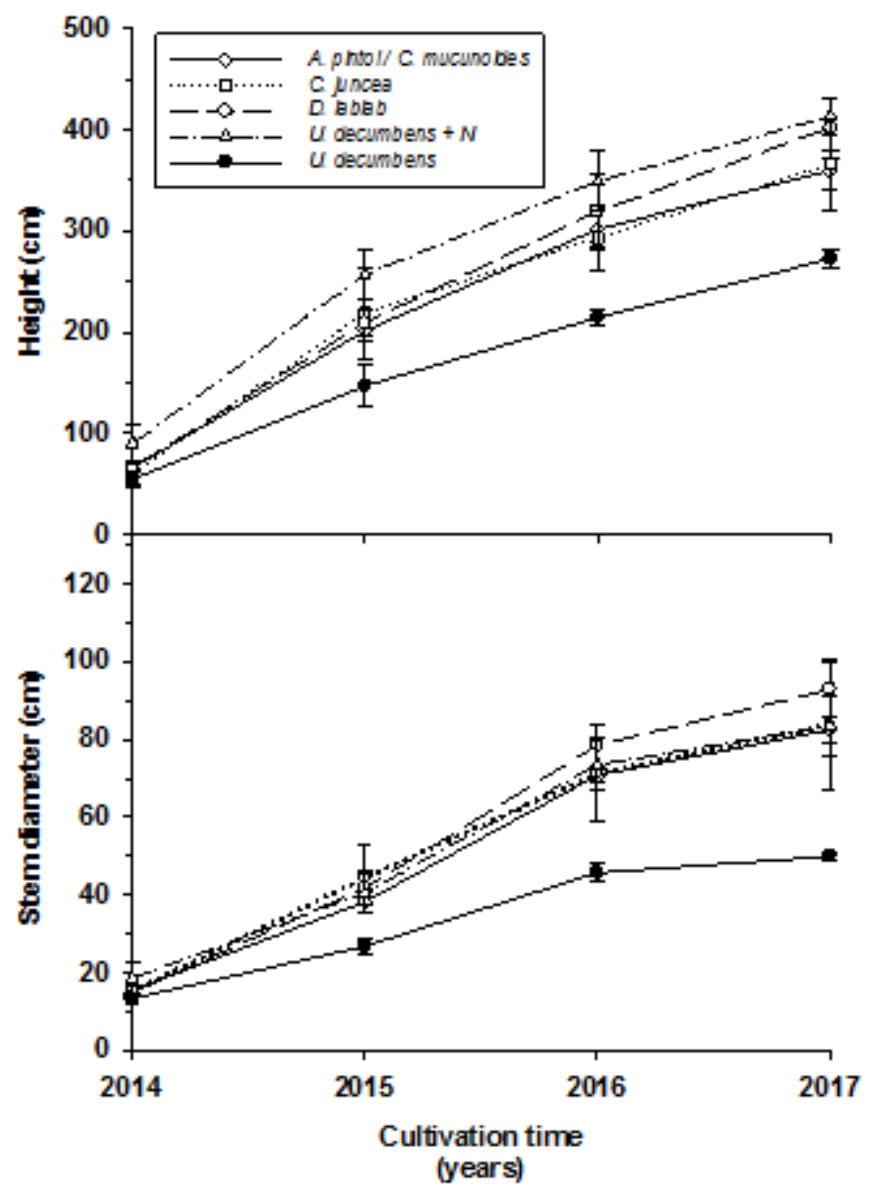

Source: Authors.

The consortium of $D$. alata with $U$. decumbens provided less height and diameter in the plants of $D$. alata, after the $4^{\text {th }}$ year (Figure 1 and Table 2). It is worth mentioning that $C$. mucunoides is a perennial fabacea, unlike the others, which are annual. This characteristic causes the plant to present, in its initial establishment, a lower growth rate, bringing less benefits to the environment to which it is inserted. It is believed that the result will be significant in the long term, after its full establishment, where the soil will not be uncovered, thus avoiding the luminous incidence, inhibiting the emergence and the development of weeds (Teodoro et al., 2011). It is important to note that $C$. mucunoides also incorporates into the soil, a substantial amount of nitrogen, from the biological nitrogen fixation process (Moreira et al., 2014).

In 2014, D. alata plants exhibited greater heights and diameter with coverage of $U$. decumbens $+\mathrm{N}$. The areas with $D$. lablab provided the plants with higher production of fresh matter (MF) and dry matter (MS), with soils with higher humidity. Consortia with $C$. juncea, $U$. decumbens and $C$. mucunoides did not stand out (Figure 2). Similar behavior was observed in other studies (Carlos et al., 2014; de Moraes Sá et al., 2015). In 2015, the two main components explained approximately 70\% of the variation captured by the variables. There was a low correlation of Fe, MF and MS with other variables. The $U$. decumbens $+\mathrm{N}$ consortium provided higher leaf contents of $\mathrm{Mg}, \mathrm{Mn}, \mathrm{Ca}$ in D. alata plants; greater MS and MF materials and greater heights. Such behavior, also, was identified in other works with D. alata (Machado et al., 2014). The consortia of $D$. alata with $C$. juncea or with $D$. lablab had a positive impact on the leaf contents of $\mathrm{Zn}, \mathrm{Cu}$ and $\mathrm{N}$ and on the stem diameter of the plants (Figure 3). Studies with nitrogen fertilizers in cover crops can be seen in (Kandel et al., 2018; Portugal et al., 2018). 
Figure 2. Nutrient content in D. alata leaves intercropped with green manures in 2014.

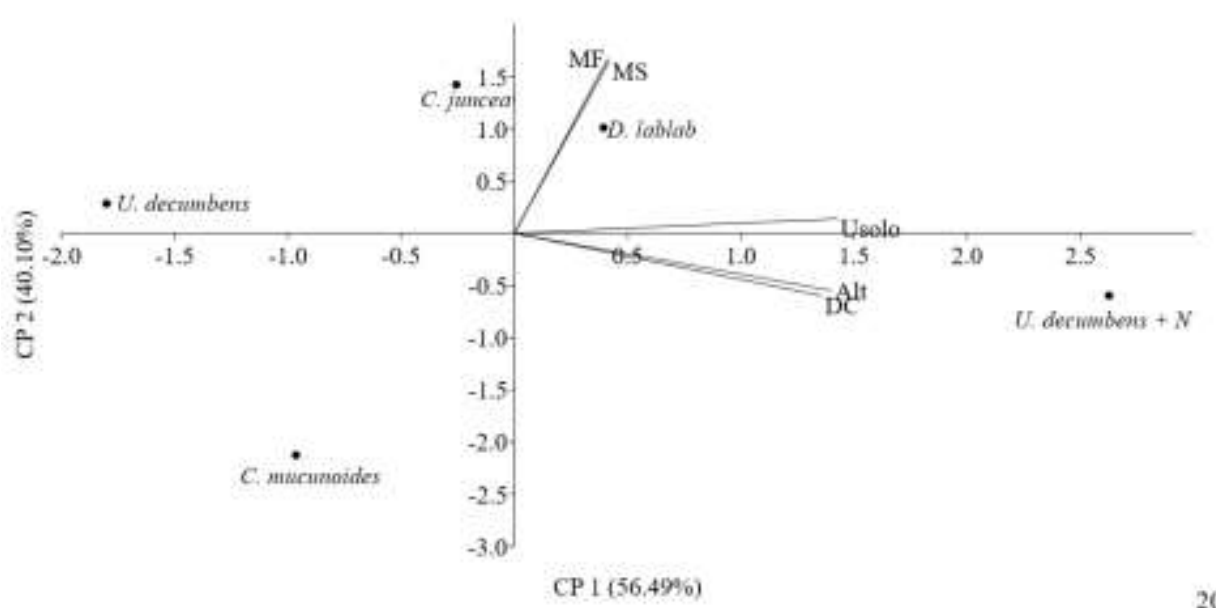

Source: Authors.

Figure 3. Nutrient content in D. alata leaves intercropped with green manures in 2015.

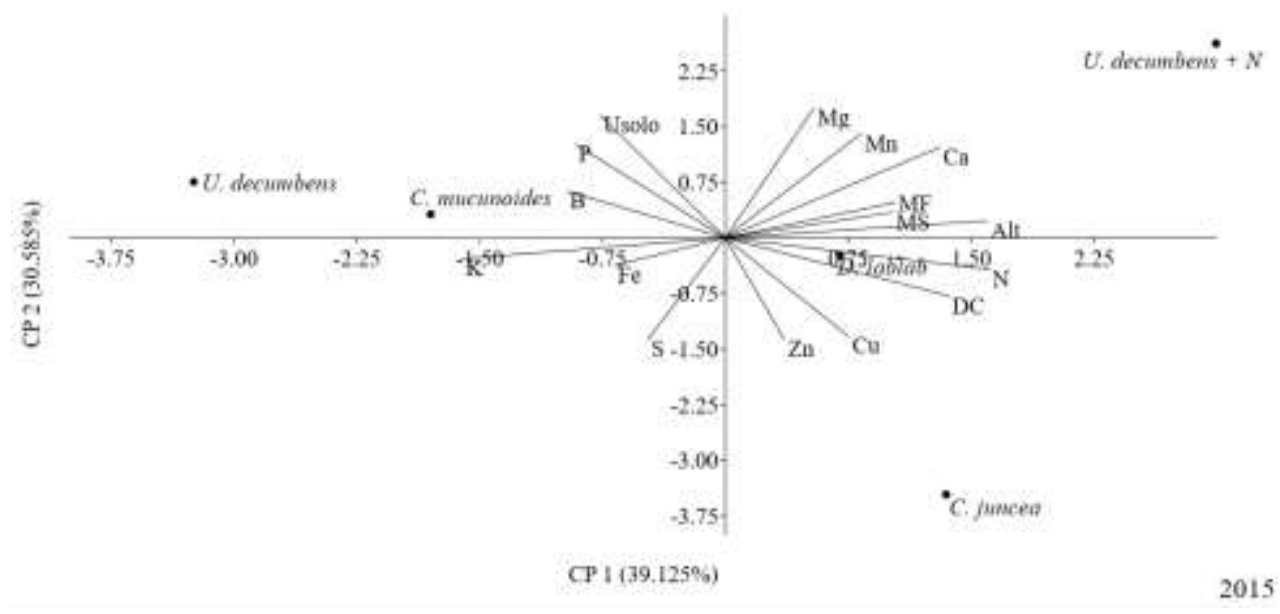

Source: Authors.

In 2016, the main components explained approximately $66 \%$ of the variation captured by the variables. For MF and MS, as observed in 2015, they had a low correlation. The intercropping with plants of $U$. decumbens $+\mathrm{N}$ and $C$. mucunoides provided plants of $D$. alata with higher leaf contents of $\mathrm{P}$ and Fe. The consortium with D. lablab had a positive impact on the leaf contents of $\mathrm{N}, \mathrm{K}$ and $\mathrm{Cu}$ (Figure 4), as well as the diameter and height of plants showing precocious fructification, where in the $4^{\text {th }}$ year, $5 \%$ of the D. alata plants started to bear fruit in the consortia with A. pintoi /C. mucunoides, U. decumbens $+\mathrm{N}$ and $D$. lablab. It is noteworthy that in the other consortia, there was no fruiting. There is a special highlight for the 5th year, where the D. lablab and $U$. decumbens consortia occurred, $10 \%$ of D. alata fruited plants. 
Figure 4. Nutrient content in D. alata leaves intercropped with green manures in 2016.

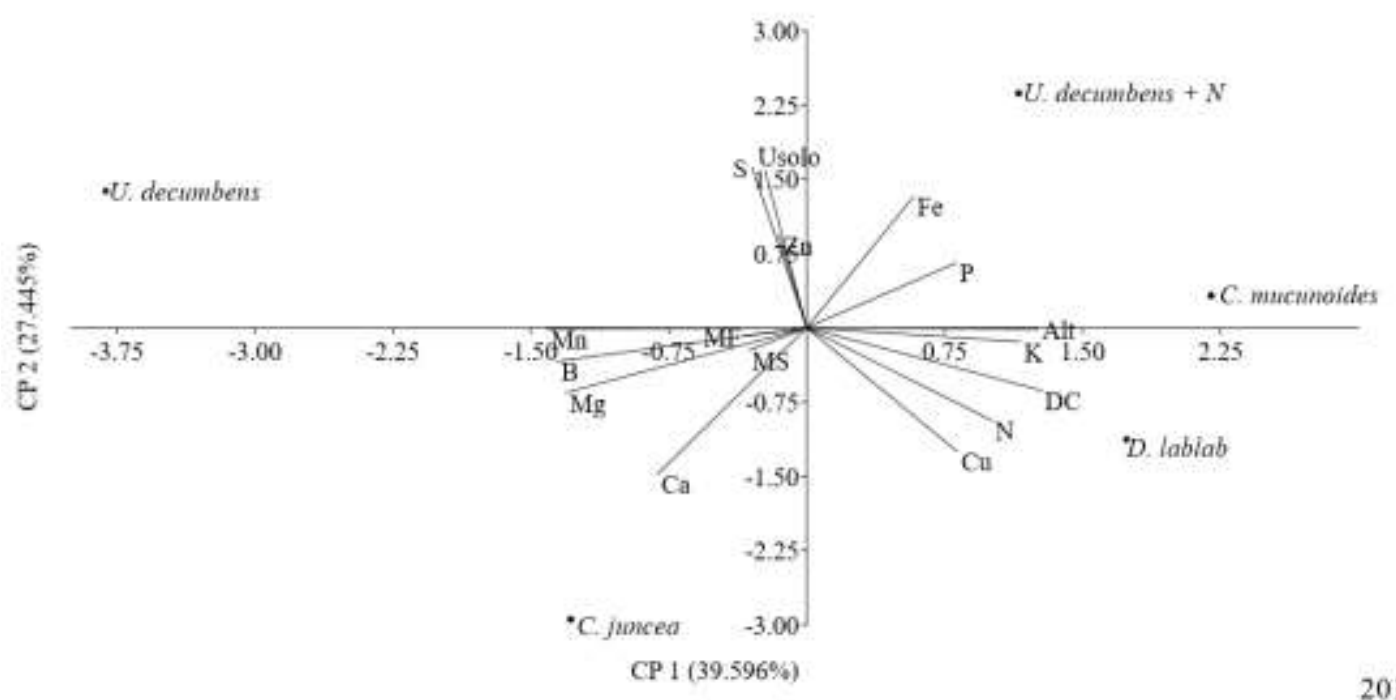

Source: Authors.

Nitrogen fertilization has shown satisfactory results (Ebúrneo et al., 2018; Portugal et al., 2018). There is a fundamental role of $\mathrm{K}$ in the growth and development of plants (Ruthrof et al., 2018; Tighe-Neira et al., 2018). The consortium with $C$. juncea caused the highest levels of $\mathrm{Ca}, \mathrm{Mg}, \mathrm{B}$ and $\mathrm{Mn}$. In 2017, the main components explained approximately $70 \%$ of the variation captured by the variables. The cover with plants of $U$. decumbens $+\mathrm{N}$ and $C$. juncea provided the plants of $D$. alata with higher leaf contents of $\mathrm{Ca}$ and $\mathrm{Mn}$ and height. The consortia with D. lablab and C. mucunoides had a positive impact on leaf contents of $\mathrm{Mg}, \mathrm{S}$ and plant diameter. The coverage with $\mathrm{U}$. decumbens contributed to higher leaf levels of $\mathrm{Cu}$, Fe, MS and soil moisture (Figure 5). Similar results were also obtained by other researchers (Delarmelinda et al., 2010; Dias et al., 2011).

Figure 5. Nutrient content in D. alata leaves intercropped with green manures in 2017.

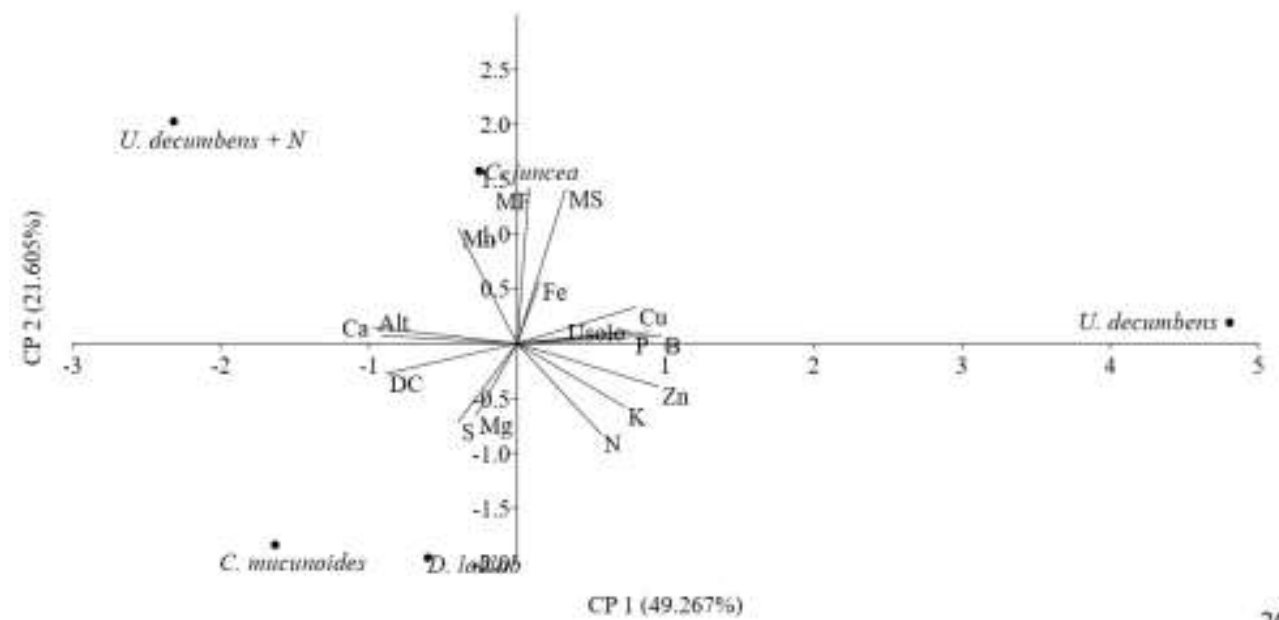

CP $1(49.267 \%)$

Source: Authors. 
Research, Society and Development, v. 10, n. 3, e55810313673, 2021

(CC BY 4.0) | ISSN 2525-3409 | DOI: http://dx.doi.org/10.33448/rsd-v10i3.13673

Regarding 2015, it was possible to identify the following significant correlations: positive correlation (Humidity and P; MF and MS) and negative correlation (Ca and S; Fe and Zn) (Table 3). For the year 2017, positive correlation (Humidity and P; height and DC; N and P; P and B; B and Zn) and negative correlation (DC and humidity; DC and P; DC and B; height and $\mathrm{B} ; \mathrm{N}$ and $\mathrm{Mn}$; $\mathrm{Ca}$ and $\mathrm{B} ; \mathrm{Ca}$ and $\mathrm{Zn}$ ). In 2017, the amplitude between the variables analyzed was greater, thus justifying the greater number of correlated variables. 
Table 3. Average value in height $(\mathrm{cm})$, stem diameter $(\mathrm{mm})$ of the $D$. alata plant, chemical and physical properties of the soil removed from the analyzed layers for the cultivation of the native fruit of the cerrado, in consortium with the cover plants, between the years 2014 to 2017.

\begin{tabular}{|c|c|c|c|c|c|c|c|}
\hline 2014 & Height & Diameter & Humidity & $\mathrm{N}$ & $\mathrm{P}$ & $\mathrm{K}$ & $\mathrm{Ca}$ \\
\hline C. mucunoides & $65.25 \mathrm{a}$ & $15.48 \mathrm{a}$ & $18.34 \mathrm{ab}$ & - & - & - & - \\
\hline C. juncea & $60.50 \mathrm{a}$ & $15.06 \mathrm{a}$ & $18.99 \mathrm{ab}$ & - & - & - & - \\
\hline D. lablab & $66.00 \mathrm{a}$ & $14.84 \mathrm{a}$ & $21.20 \mathrm{ab}$ & - & - & - & - \\
\hline$U$. decumbens $+N$ & $89.75 \mathrm{a}$ & $18.52 \mathrm{a}$ & $22.66 \mathrm{~b}$ & - & - & - & - \\
\hline U. decumbens & $54.25 \mathrm{a}$ & $13.29 \mathrm{a}$ & $17.41 \mathrm{a}$ & - & - & - & - \\
\hline \multicolumn{8}{|l|}{2015} \\
\hline C. mucunoides & $201.25 \mathrm{a}$ & $38.16 \mathrm{a}$ & $17.94 \mathrm{ab}$ & $1.90 \mathrm{a}$ & $0.54 \mathrm{a}$ & $0.89^{\mathrm{bc}}$ & $1.45 \mathrm{abc}$ \\
\hline C. juncea & $219.00 \mathrm{a}$ & $44.38 \mathrm{a}$ & $15.63 \mathrm{a}$ & $2.40 \mathrm{~b}$ & $0.18 \mathrm{a}$ & $0.72 \mathrm{abc}$ & $1.35 \mathrm{ab}$ \\
\hline D. lablab & $209.25 \mathrm{a}$ & $41.73 \mathrm{a}$ & $16.52 \mathrm{ab}$ & $2.20 \mathrm{ab}$ & $0.16 \mathrm{a}$ & $0.56 \mathrm{ab}$ & $1.61 \mathrm{bc}$ \\
\hline$U$. decumbens $+N$ & $257.25 \mathrm{a}$ & $40.54 \mathrm{a}$ & $18.06 \mathrm{ab}$ & $2.40 \mathrm{~b}$ & $0.45 \mathrm{a}$ & $0.48 \mathrm{a}$ & $2.35 \mathrm{c}$ \\
\hline U. decumbens & $146.75 \mathrm{a}$ & $26.74 \mathrm{a}$ & $18.43 \mathrm{~b}$ & $1.90 \mathrm{a}$ & $0.54 \mathrm{a}$ & $1.04 \mathrm{c}$ & $1.22 \mathrm{a}$ \\
\hline \multicolumn{8}{|l|}{2016} \\
\hline C. mucunoides & $302.00 \mathrm{ab}$ & $70.79 \mathrm{a}$ & $19.15 \mathrm{ab}$ & $1.75 \mathrm{ab}$ & $0.13 \mathrm{a}$ & $0.74 \mathrm{~b}$ & $1.10 \mathrm{ab}$ \\
\hline C. juncea & $293.00 \mathrm{ab}$ & $71.19 \mathrm{a}$ & $13.21 \mathrm{a}$ & $1.82 \mathrm{ab}$ & $0.08 \mathrm{a}$ & $0.38 \mathrm{ab}$ & $2.41 \mathrm{~b}$ \\
\hline D. lablab & $319.50 \mathrm{ab}$ & $78.51 \mathrm{a}$ & $14.83 \mathrm{a}$ & $2.10 \mathrm{~b}$ & $0.12 \mathrm{a}$ & $0.72 \mathrm{~b}$ & $1.62 \mathrm{ab}$ \\
\hline$U$. decumbens $+N$ & $349.00 \mathrm{~b}$ & $73.43 \mathrm{a}$ & $18.60 \mathrm{ab}$ & $1.75 \mathrm{ab}$ & $0.10 \mathrm{a}$ & $0.44 \mathrm{ab}$ & $0.73 \mathrm{a}$ \\
\hline U. decumbens & $214.25 \mathrm{a}$ & $45.67 \mathrm{a}$ & $20.23 \mathrm{~b}$ & $1.50 \mathrm{a}$ & $0.10 \mathrm{a}$ & $0.38 \mathrm{a}$ & $1.71 \mathrm{ab}$ \\
\hline \multicolumn{8}{|l|}{2017} \\
\hline C. mucunoides & $360.00 \mathrm{ab}$ & $82.47 \mathrm{ab}$ & $14.5 \mathrm{a}$ & $2.18 \mathrm{a}$ & $0.12 \mathrm{a}$ & $0.66 \mathrm{ab}$ & $1.70 \mathrm{a}$ \\
\hline C. juncea & $366.25 \mathrm{ab}$ & $83.76 \mathrm{ab}$ & $11.83 \mathrm{a}$ & $2.23 \mathrm{a}$ & $0.11 \mathrm{a}$ & $0.72 \mathrm{ab}$ & $1.59 \mathrm{a}$ \\
\hline D. lablab & $402.25 \mathrm{ab}$ & $92.83 \mathrm{~b}$ & $12.14 \mathrm{a}$ & $2.28 \mathrm{a}$ & $0.11 \mathrm{a}$ & $0.72 \mathrm{ab}$ & $1.53 \mathrm{a}$ \\
\hline$U$. decumbens $+N$ & $414.00 \mathrm{~b}$ & $83.47 \mathrm{ab}$ & $14.68 \mathrm{a}$ & $2.03 \mathrm{a}$ & $0.12 \mathrm{a}$ & $0.54 \mathrm{a}$ & $1.73 \mathrm{a}$ \\
\hline U. decumbens & $272.50 \mathrm{a}$ & $49.88 \mathrm{a}$ & $19.90 \mathrm{a}$ & $2.25 \mathrm{a}$ & $0.19 \mathrm{a}$ & $0.76 \mathrm{~b}$ & $1.27 \mathrm{a}$ \\
\hline 2014 & $\mathrm{Mg}$ & $\mathrm{S}$ & $\mathrm{B}$ & $\mathrm{Fe}$ & $\mathrm{Cu}$ & $\mathrm{Mn}$ & $\mathrm{Zn}$ \\
\hline C. mucunoides & - & - & - & - & - & - & - \\
\hline C. juncea & - & - & - & - & - & - & - \\
\hline D. lablab & - & - & - & - & - & - & - \\
\hline U. decumbens $+N$ & - & - & - & - & - & - & - \\
\hline U. decumbens & - & - & - & - & - & - & - \\
\hline \multicolumn{8}{|l|}{2015} \\
\hline C. mucunoides & $0.37 \mathrm{bc}$ & $0.03 \mathrm{abc}$ & $34.00 \mathrm{c}$ & $462.00 \mathrm{ab}$ & $15.00 \mathrm{bc}$ & $174.00 \mathrm{bc}$ & $28.40 \mathrm{ab}$ \\
\hline C. juncea & $0.26 \mathrm{a}$ & $0.17 \mathrm{c}$ & $17.00 \mathrm{a}$ & $503.00 \mathrm{abc}$ & $20.00 \mathrm{c}$ & $155.00 \mathrm{ab}$ & $34.00 \mathrm{~b}$ \\
\hline
\end{tabular}


Research, Society and Development, v. 10, n. 3, e55810313673, 2021

(CC BY 4.0) | ISSN 2525-3409 | DOI: http://dx.doi.org/10.33448/rsd-v10i3.13673

\begin{tabular}{llllllll} 
D. lablab & $0.35 \mathrm{abc}$ & $0.02 \mathrm{ab}$ & $30.00 \mathrm{bc}$ & $610.00 \mathrm{c}$ & $11.00 \mathrm{abc}$ & $147.00 \mathrm{a}$ & $20.00 \mathrm{a}$ \\
U. decumbens $+N$ & $0.44 \mathrm{c}$ & $0.01 \mathrm{a}$ & $21.00 \mathrm{ab}$ & $446.00 \mathrm{a}$ & $10.00 \mathrm{ab}$ & $245.00 \mathrm{c}$ & $23.00 \mathrm{ab}$ \\
U. decumbens & $0.32 \mathrm{ab}$ & $0.13 \mathrm{bc}$ & $26.00 \mathrm{abc}$ & $586.00 \mathrm{bc}$ & $3.00 \mathrm{a}$ & $167.00 \mathrm{abc}$ & $20.00 \mathrm{a}$ \\
\hline $\mathbf{2 0 1 6}$ & & & & & & & \\
C. mucunoides & $0.26 \mathrm{a}$ & $0.02 \mathrm{a}$ & $31.75 \mathrm{a}$ & $344.25 \mathrm{ab}$ & $4.75 \mathrm{a}$ & $54.25 \mathrm{a}$ & $19.25 \mathrm{ab}$ \\
C. juncea & $0.30 \mathrm{a}$ & $0.01 \mathrm{a}$ & $41.50 \mathrm{a}$ & $166.25 \mathrm{a}$ & $4.50 \mathrm{a}$ & $299.25 \mathrm{ab}$ & $13.25 \mathrm{a}$ \\
D. lablab & $0.25 \mathrm{a}$ & $0.02 \mathrm{a}$ & $36.50 \mathrm{a}$ & $179.75 \mathrm{ab}$ & $4.75 \mathrm{a}$ & $185.50 \mathrm{ab}$ & $58.25 \mathrm{~b}$ \\
U. decumbens $+N$ & $0.25 \mathrm{a}$ & $0.03 \mathrm{a}$ & $28.50 \mathrm{a}$ & $614.25 \mathrm{~b}$ & $3.75 \mathrm{a}$ & $84.25 \mathrm{a}$ & $49.25 \mathrm{~b}$ \\
$U$. decumbens & $0.30 \mathrm{a}$ & $0.03 \mathrm{a}$ & $51.60 \mathrm{a}$ & $216.00 \mathrm{ab}$ & $3.80 \mathrm{a}$ & $623.20 \mathrm{~b}$ & $53.80 \mathrm{~b}$ \\
\hline $\mathbf{2 0 1 7}$ & & & & & & & \\
C. mucunoides & $0.28 \mathrm{a}$ & $0.03 \mathrm{a}$ & $37.25 \mathrm{a}$ & $224.00 \mathrm{a}$ & $5.25 \mathrm{a}$ & $129.50 \mathrm{a}$ & $26.00 \mathrm{ab}$ \\
C. juncea & $0.24 \mathrm{a}$ & $0.01 \mathrm{a}$ & $40.75 \mathrm{ab}$ & $243.75 \mathrm{a}$ & $6.75 \mathrm{ab}$ & $163.00 \mathrm{a}$ & $26.00 \mathrm{ab}$ \\
D. lablab & $0.27 \mathrm{a}$ & $0.01 \mathrm{a}$ & $41.00 \mathrm{ab}$ & $203.25 \mathrm{a}$ & $7.50 \mathrm{ab}$ & $143.75 \mathrm{a}$ & $30.00 \mathrm{ab}$ \\
$U$. decumbens $+N$ & $0.28 \mathrm{a}$ & $0.01 \mathrm{a}$ & $37.50 \mathrm{ab}$ & $210.25 \mathrm{a}$ & $7.00 \mathrm{ab}$ & $363.00 \mathrm{a}$ & $22.25 \mathrm{a}$ \\
U. decumbens & $0.27 \mathrm{a}$ & $0.01 \mathrm{a}$ & $76.50 \mathrm{~b}$ & $221.25 \mathrm{a}$ & $9.00 \mathrm{~b}$ & $154.75 \mathrm{a}$ & $39.50 \mathrm{~b}$ \\
\hline
\end{tabular}

Averages followed by the same letter do not differ according to the Kruskal-Wallis test ( $p>0.05)$.

Source: Authors. 
The results of the evaluation of the variables in relation to the grouping show that there was no clear segregation in the variables when compared to the distribution. In general, according to the cluster analysis (Figure 6), there was a grouping between all the consortium combinations for the years 2014 to 2017. However, in 2017, it was found that the consortium of $D$. alata plants with $U$. decumbens $+\mathrm{N}$ differed from the others, characterized by the dominance among cover plants consortia, highlighting nitrogen fertilization. $U$. decumbens $+\mathrm{N}$, D. lablab and $C$. juncea were the treatments that provided the best performance in the development of $D$. alata. It is worth mentioning that, in the case of D. lablab and $C$. juncea, they are cover plants that did not have the insertion of chemical fertilizers, thus providing the practice of sustainable use of the Cerrado soil. Practices such as crop rotation can improve soil quality and, consequently, increase production rates, both in organic and conventional systems (Bai et al., 2018).

Figure 6. Multivariate Clusters - grouping between all combinations of consortia of cover plants between the years 2014 to 2017.

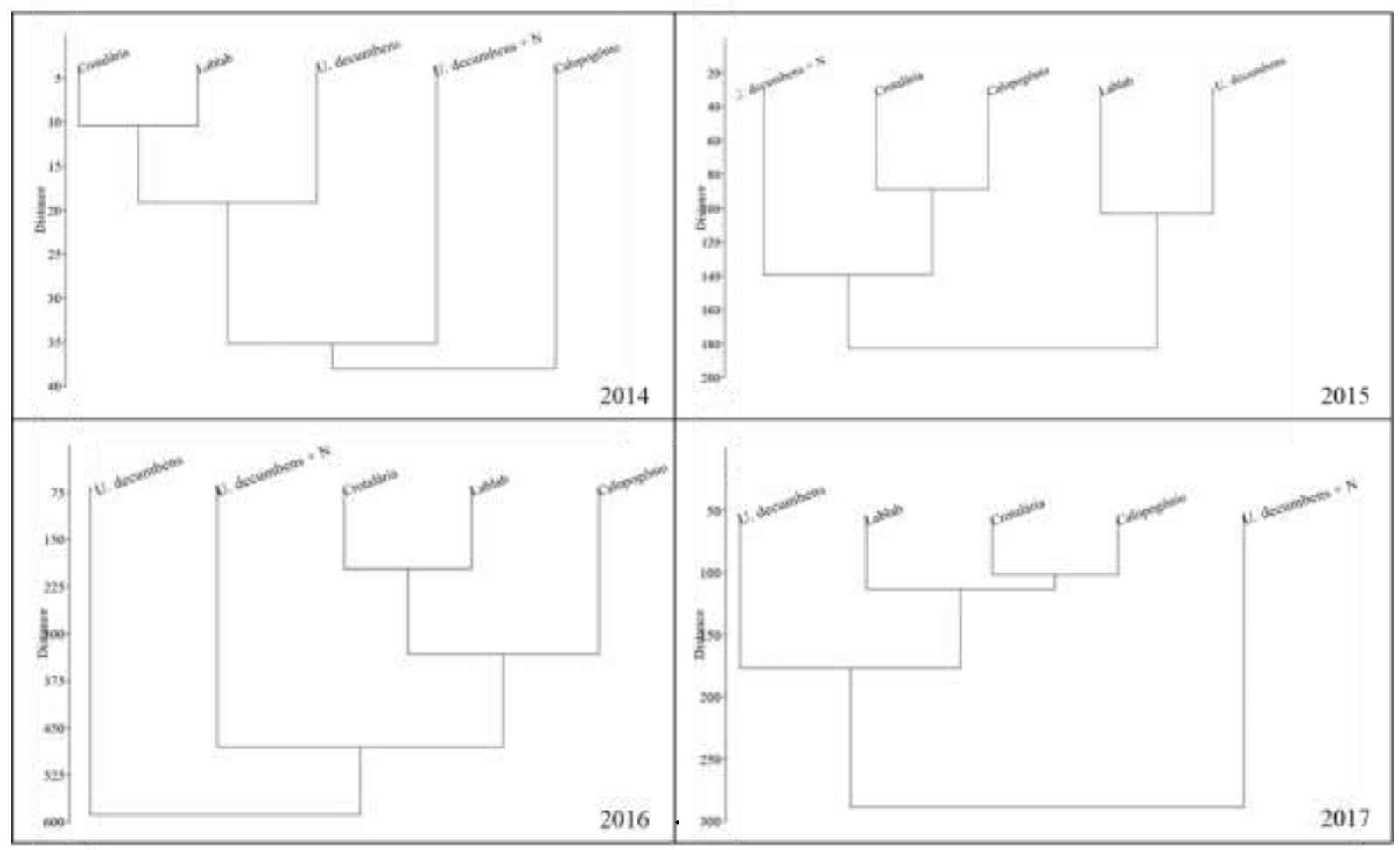

Source: Authors.

\section{Conclusion}

Although they have less capacity to maintain humidity levels, U. decumbens $+\mathrm{N}$, C. juncea, D. lablab and $C$. mucunoides were the cover plants that conferred the highest nitrogen content in D. alata. C. mucunoides produced the lowest amount of biomass, however it provided the lowest moisture losses in 2015 and 2017. Among the studied consortia $U$. decumbens $+\mathrm{N}, D$. lablab and $C$. juncea, were the treatments that provided the best performance in the development of $D$. alata. Thus, further studies on D. alata discharged in consortium with more varieties of cover plants should be carried out, in order to contribute to the understanding of the interaction between these plants.

\section{Acknowledgments}

To the Federal Institute of Goiás - Campus Rio Verde, for the concession of the experimental area, machinery, 
agricultural equipment and operators for conducting and maintaining the experiment.

\section{References}

Aguilar-Fenollosa, E., \& Jacas, J. A. (2013). Effect of ground cover management on Thysanoptera (thrips) in clementine mandarin orchards. Journal of Pest Science, 86(3), 469-481. https://doi.org/10.1007/s10340-013-0494-x

American Public Health Association. APHA (2005) Standard Methods for the Examination of Water and Wastewater. (21st ed.), American Public Health Association, 1220

Andaló, V., Mieko, J., Carvalho, F. J., de Assis, G. A., de Faria, L. S., de Assis, F. A., dos Santos, R. A., \& Rosa, F. (201 8). Entomopathogenic nematode distribution and edaphoclimatic conditions in the Cerrado of Minas Gerais, Brazil. Applied Entomology and Zoology, 53(1), 129-136. https://doi.org/10.1007/s13355-017-0538-4

Bai, Z., Caspari, T., Gonzalez, M. R., Batjes, N. H., Mäder, P., Bünemann, E. K., de Goede, R., Brussaard, L., Xu, M., Ferreira, C. S. S., Reintam, E., Fan, H., Mihelič, R., Glavan, M., \& Tóth, Z. (2018). Effects of agricultural management practices on soil quality: A review of long-term experiments for Europe and China. Agriculture, Ecosystems and Environment, 265, 1-7. https://doi.org/10.1016/j.agee.2018.05.028

Carlos, L., Venturin, N., Macedo, R. L. G., Higashikawa, E. M., Garcia, M. B., \& Farias, E. de S. (2014). Crescimento e nutrição mineral de mudas de pequi sob efeito da omissão de nutrientes. Ciencia Florestal, 24(1), 13-21. https://doi.org/10.5902/1980509813318

Carrazza, L. R., \& Ávila, J. C. C. (2010). Manual Tecnológico de Aproveitamento Integral do Fruto do Baru (2nd ed.). Instituto Sociedade, População e Natureza.

Chapin, F. S., Matson, P. A., Vitousek, P. M., Chapin, F. S., Matson, P. A., \& Vitousek, P. M. (2011). Landscape Heterogeneity and Ecosystem Dynamics. In Principles of Terrestrial Ecosystem Ecology (pp. 369-397). https://doi.org/10.1007/978-1-4419-9504-9_13

Coelho, F. S., Fontes, P. C. R., Finger, F. L., \& Cecon, P. R. (2012). Avaliação do estado nutricional do nitrogênio em batateira por meio de polifenóis e clorofila na folha. Pesquisa Agropecuaria Brasileira, 47(4), 584-592. https://doi.org/10.1590/S0100-204X2012000400015

Coradin, L., Siminski, A., \& Reis, A. (2011). Espécies Nativas da Flora Brasileira de Valor Econômico Atual ou Potencial: Plantas para o Futuro - Região Sul. Ministério do Meio Ambiente.

Corrêa, A. L., de Souza Abboud, A. C., Guerra, J. G. M., de Aguiar, L. A., \& Ribeiro, R. de L. D. (2014). Adubação verde com crotalária consorciada ao minimilho antecedendo a couve-folha sob manejo orgânico. Revista Ceres, 61(6), 956-963. https://doi.org/10.1590/0034-737X201461060010

de Andrade Silva, C. A., \& Fonseca, G. G. (2016). Brazilian savannah fruits: Characteristics, properties, and potential applications. In Food Science and Biotechnology (Vol. 25, Issue 5, pp. 1225-1232). Kluwer Academic Publishers. https://doi.org/10.1007/s10068-016-0195-3

de Carvalho Mendes, I., Fernandes, M. F., Chaer, G. M., \& Bueno dos Reis Junior, F. (2012). Biological functioning of Brazilian Cerrado soils under different vegetation types. Plant and Soil, 359(1-2), 183-195. https://doi.org/10.1007/s11104-012-1195-6

de Moraes Sá, J. C., Séguy, L., Tivet, F., Lal, R., Bouzinac, S., Borszowskei, P. R., Briedis, C., dos Santos, J. B., da Cruz Hartman, D., Bertoloni, C. G., Rosa, J., \& Friedrich, T. (2015). Carbon Depletion by Plowing and its Restoration by No-Till Cropping Systems in Oxisols of Subtropical and Tropical AgroEcoregions in Brazil. Land Degradation \& Development, 26(6), 531-543. https://doi.org/10.1002/ldr.2218

Delarmelinda, E. A., Sampaio, F. A. R., Dias, J. R. M., Tavella, L. B., \& de Silva, J. S. (2010). Green manure and changes on chemical characteristics of a soil in the Ji-Paraná-RO region. Acta Amazonica, 40(3), 625-628. https://doi.org/10.1590/s0044-59672010000300024

Dias, J. R. M., Wadt, P. G. S., Folle, F. A., Solino, A. J. da S., Delarmelinda, E. A., \& Tavella, L. B. (2011). Response potential to fertilization response for N, $\mathrm{P}, \mathrm{K}, \mathrm{Ca}$ and $\mathrm{Mg}$ in cupuaçueiros evaluated by different DRIS standards. Acta Amazonica, 41(1), 77-82. https://doi.org/10.1590/s0044-59672011000100009

Donado-Pestana, C. M., dos Santos-Donado, P. R., Daza, L. D., Belchior, T., Festuccia, W. T., \& Genovese, M. I. (2018). Cagaita fruit (Eugenia dysenterica DC.) and obesity: Role of polyphenols on already established obesity. Food Research International, 103, 40-47. https://doi.org/10.1016/j.foodres.2017.10.011

Ebúrneo, J. M., Garcia, E. L., dos Santos, T. P. R., de Souza, E. de F. C., Soratto, R. P., Fernandes, A. M., \& Leonel, M. (2018). Influence of nitrogen fertilization on the characteristics of potato starch. Australian Journal of Crop Science, 12(3), 365-373. https://doi.org/10.21475/ajcs.18.12.03.pne680

Franco, R. R., Mota Alves, V. H., Ribeiro Zabisky, L. F., Justino, A. B., Martins, M. M., Saraiva, A. L., Goulart, L. R., \& Espindola, F. S. (2020). Antidiabetic potential of Bauhinia forficata Link leaves: a non-cytotoxic source of lipase and glycoside hydrolases inhibitors and molecules with antioxidant and antiglycation properties. Biomedicine and Pharmacotherapy, 123, 109798. https://doi.org/10.1016/j.biopha.2019.109798

Garcia-Franco, N., Albaladejo, J., Almagro, M., \& Martínez-Mena, M. (2015). Beneficial effects of reduced tillage and green manure on soil aggregation and stabilization of organic carbon in a Mediterranean agroecosystem. Soil and Tillage Research, 153, 66-75. https://doi.org/10.1016/j.still.2015.05.010

Garcia-Franco, Noelia, Hobley, E., Hübner, R., \& Wiesmeier, M. (2018). Climate-Smart Soil Management in Semiarid Regions. In Soil Management and Climate Change: Effects on Organic Carbon, Nitrogen Dynamics, and Greenhouse Gas Emissions (pp. 349-368). Elsevier Inc. https://doi.org/10.1016/B978$0-12-812128-3.00023-9$

Gitti, D. de C., Arf, O., Portugal, J. R., Corsini, D. C. D. C., Rodrigues, R. A. F., \& Kaneko, F. H. (2012). Coberturas vege tais, doses de nitrogênio e inoculação de sementes com Azospirillum brasilense em arroz de terras altas no sistema plantio direto. Bragantia, 71(4), 509-517. https://doi.org/10.1590/S0006-87052013005000002

Gupta, B., Shah, D. O., Mishra, B., Joshi, P. A., Gandhi, V. G., \& Fougat, R. S. (2015). Effect of top soil wettability on water evaporation and plant growth Journal of Colloid and Interface Science, 449, 506-513. https://doi.org/10.1016/j.jcis.2015.02.018 
Júnior de Almeida, H., José Cruz, F. R., Alexandre Pancelli, M., Alves Flores, R., de Lima Vasconcelos, R., \& de Mello Prado, R. (2015). Decreased potassium fertilization in sugarcane ratoons grown under straw in different soils. In AJCS. 9(7).

Kandel, T. P., Gowda, P. H., Somenahally, A., Northup, B. K., DuPont, J., \& Rocateli, A. C. (2018). Nitrous oxide emissions as influenced by legume cover crops and nitrogen fertilization. Nutrient Cycling in Agroecosystems, 112(1), 119-131. https://doi.org/10.1007/s10705-018-9936-4

Korte, N., \& Porembski, S. (2010). Eignung diverser Einsaatpflanzen und -mischungen für ein neues Konzept der Baumstreifenbegrünung im biologischen Obstbau. Gesunde Pflanzen, 62(2), 45-52. https://doi.org/10.1007/s10343-010-0220-z

Landim, P. M. B. (2011). Análise estatística de dados geológicos multivariados. Oficina de Texto.

López-Bellido, R. J., López-Bellido, L., Castillo, J. E., \& López-Bellido, F. J. (2004). Chickpea response to tillage and soil residual nitrogen in a continuous rotation with wheat: II. Soil nitrate, N uptake and influence on wheat yield. Field Crops Research, 88(2-3), 201-210. https://doi.org/10.1016/j.fcr.2004.01.012

Machado, N. G., Aquino, B. G., \& Neves, G. A. P. C. (2014). Espécies Nativas De Plantas Frutíferas Em Uma Área De Cerrado Em Mato Grosso, BrasiL. Revista Monografias Ambientais, 13(3), 3306-3315. https://doi.org/10.5902/2236130813068

Malavolta, E., Vitti, G. C., \& De Oliveira, S. A. (1997). Avaliação do estado nutricional das plantas: princípios e aplicações (2nd ed.). Patafós.

Ministério do Meio Ambiente (MMA). (2014). Plano de ação para prevenção e controle do desmatamento e das queimadas do Cerrado: $2^{\circ}$ fase (2014-2015). Brasília. < http://www.mma.gov.br/images/arquivos/florestas/controle_e_prevencao/PPCerrado/PPCerrado_2fase.pdf>

Moreira, V., Justino, G. C., Camargos, L. S., \& Aguiar, L. F. (2014). Adaptive characteristics of the symbiotic association and nitrogen symbiotic fixation in young plants of Lonchocarpus muehlbergianus Haasl., a leguminous tree native from "Cerrado." Rodriguesia, 65(2), 517-525. https://doi.org/10.1590/s217578602014000200013

Nemecek, T., Hayer, F., Bonnin, E., Carrouée, B., Schneider, A., \& Vivier, C. (2015). Designing eco-efficient crop rotations using life cycle assessment of crop combinations. European Journal of Agronomy, 65, 40-51. https://doi.org/10.1016/j.eja.2015.01.005

Norgrove, L., \& Hauser, S. (2013). Black leaf streak disease and plantain fruit characteristics as affected by tree density and biomass management in a tropic al agroforestry system. Agroforestry Systems, 87(2), 349-354. https://doi.org/10.1007/s10457-012-9555-z

Oliveira, V. B., Yamada, L. T., Fagg, C. W., \& Brandão, M. G. L. (2012). Native foods from Brazilian biodiversity as a source of bioactive compounds. Food Research International, 48(1), 170-179. https://doi.org/10.1016/j.foodres.2012.03.011

Paulo, D., Adriano, P., Fabiano, G. S., Aurélio, R. N., \& Gabriel, B. M. (2016). Water content and soil nutrient in consortium of native fruit trees with cover crops. African Journal of Agricultural Research, 11(41), 4100-4108. https://doi.org/10.5897/ajar2016.11414

Perin, A., Guerra, J. G. M., Espindola, J. A. A., Teixeira, M. G., \& Busquet, R. N. B. (2009). Banana plant performance intercropping with perennial herbaceous legumes. Ciencia e Agrotecnologia, 33(6), 1511-1517. https://doi.org/10.1590/s1413-70542009000600008

Portugal, J. R., Arf, O., Peres, A. R., Meirelles, F. C., Ferreira Rodrigues, R. A., Gonzaga, A. R., Siviero Garcia, N. F., \& Corsini, D. C. D. C. (2018). Nutritional aspects of corn due to cover crops, nitrogen doses and inoculation with Azospirillum brasilense. Australian Journal of Crop Science, 12(4), 592601. https://doi.org/10.21475/ajcs.18.12.04.pne864

Regazzi, A. J., \& Silva, C. H. O. (2010). Testes para verificar a igualdade de parâmetros e a identidade de modelos de regressão não-linear em dados de experimento com delineamento em blocos casualizados. Revista Ceres, 57(3), 315-320. https://doi.org/10.1590/s0034-737x2010000300005

Ruthrof, K. X., Fontaine, J. B., Hopkins, A. J. M., McHenry, M. P., O’Hara, G., McComb, J., Hardy, G. E. S. J., \& Howieson, J. (2018). Potassium amendment increases biomass and reduces heavy metal concentrations in Lablab purpureus after phosphate mining. Land Degradation and Development, 29(3), 398-407. https://doi.org/10.1002/ldr.2866

Schiassi, M. C. E. V., Souza, V. R. de, Lago, A. M. T., Campos, L. G., \& Queiroz, F. (2018). Fruits from the Brazilian Cerrado region: Physico-chemical characterization, bioactive compounds, antioxidant activities, and sensory evaluation. Food Chemistry, $245,305-311$. https://doi.org/10.1016/j.foodchem.2017.10.104

Schroth, G., Zech, W., \& Heimann, G. (1992). Mulch decomposition under agroforestry conditions in a sub-humid tropical savanna processes and influence of perennial plants. Plant and Soil, 147(1), 1-11. https://doi.org/10.1007/BF00009365

Schuberth, F., Henseler, J., \& Dijkstra, T. K. (2018). Confirmatory Composite Analysis. Frontiers in Psychology, 9(2541). https://doi.org/10.3389/fpsyg.2018.02541

Scopel, E., Triomphe, B., Affholder, F., Da Silva, F. A. M. E., Corbeels, M., Xavier, J. H. V., Lahmar, R., Recous, S., Bernoux, M., Blanchart, E., De Carvalho Mendes, I., \& De Tourdonnet, S. (2013). Conservation agriculture cropping systems in temperate and tropical conditions, performances and impacts. A review. In Agronomy for Sustainable Development. 33(1), 113-130. https://doi.org/10.1007/s13593-012-0106-9

Soares, A. N. R., Clivati, D., de Vasconcelos Melo, M. F., Gitzendanner, M., Soltis, P., Soltis, D., da Silva Júnior, J. F., da Silva Ledo, A., \& da Silva, A. V. C. (2018). Genetic Diversity of Accessions and First Generation Progeny of the Mangaba Genebank. American Journal of Plant Sciences, 09(08), 1618-1629. https://doi.org/10.4236/ajps.2018.98117

Teodoro, R. B., de Oliveira, F. L., da Silva, D. M. N., Fávero, C., \& Quaresma, M. A. L. (2011). Perennial herbaceous legumes used as permanent cover cropping in the Caatinga Mineira. Revista Ciencia Agronomica, 42(2), 292-300. https://doi.org/10.1590/s1806-66902011000200006

Thorup-Kristensen, K., Magid, J., \& Jensen, L. S. (2003). Catch crops and green manures as biological tools in nitrogen management in temperate zones. In Advances in Agronomy. 79, 227-302. https://doi.org/10.1016/S0065-2113(02)79005-6 
Research, Society and Development, v. 10, n. 3, e55810313673, 2021

(CC BY 4.0) | ISSN 2525-3409 | DOI: http://dx.doi.org/10.33448/rsd-v10i3.13673

Tighe-Neira, R., Alberdi, M., Arce-Johnson, P., Romero, J., Reyes-Díaz, M., Rengel, Z., \& Inostroza-Blancheteau, C. (2018). Role of potassium in governing photosynthetic processes and plant yield. In Plant Nutrients and Abiotic Stress Tolerance (pp. 191-203). Springer Singapore. https://doi.org/10.1007/978-981$10-9044-8 \_8$

Van Deynze, A., Zamora, P., Delaux, P.-M., Heitmann, C., Jayaraman, D., Rajasekar, S., Graham, D., Maeda, J., Gibson, D., Schwartz, K. D., Berry, A. M., Bhatnagar, S., Jospin, G., Darling, A., Jeannotte, R., Lopez, J., Weimer, B. C., Eisen, J. A., Shapiro, H.-Y., ... Bennett, A. B. (2018). Nitrogen fixation in a landrace of maize is supported by a mucilage-associated diazotrophic microbiota. PLOS Biology, 16(8), e2006352. https://doi.org/10.1371/journal.pbio.2006352. 